\title{
An Overview Of The Immediate Execution Of Amar Decisions (Uitvoebaar Bij Voorad ) In Civil Cases in The Kabanjahe State Court
}

\author{
Aries Shandy Pasca Ginting
}

Department Of Civil Law, North Sumatera University Faculty Of Law. E-mail: ariesshandy@gmail.com

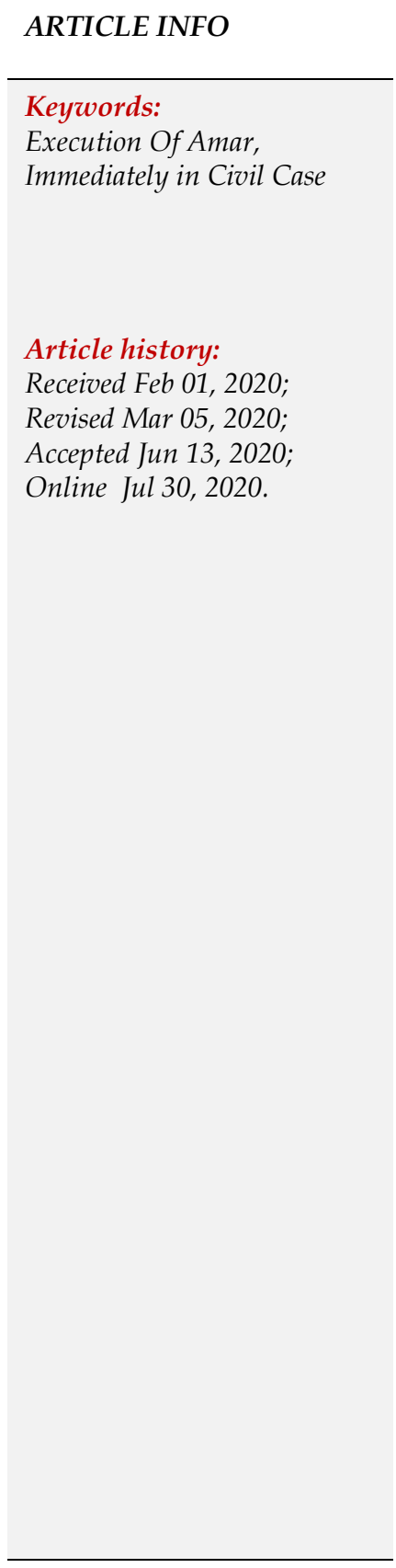

\begin{abstract}
The decision immediately (uitvoerbaar bij voorraad) is a breakthrough against the slow judicial process. Through the uitvoerbaar bij voorraad institution, the Court's decision can be executed even though the decision has not yet obtained permanent legal force. However, this uitvoerbaar bij voorraad turned out to cause many problems in its implementation practice. One of the problems that often occurs is the process of executing decisions immediately. The District Court as the spearhead of executing the decision immediately (uitvoerbaar bij voorraad) often encounters obstacles in executing the decision. Normative research is conducted by examining laws and regulations, legal materials, and other materials related to the writing of this thesis. Sociological research was conducted by conducting research at the Kabanjahe District Court. The types of data used are primary data and secondary data consisting of primary legal materials, secondary legal materials and tertiary legal materials. The existence of a guarantee by the applicant for execution is one of the conditions for the immediate execution of the decision. Without this guarantee, the execution of the decision cannot be carried out immediately. Barriers to the immediate execution of the decision (uitvoerbaar bij voorraad) at the Kabanjahe District Court were not the immediate issuance of an execution permit by the Head of the Medan High Court, the applicant for execution was unable to submit guarantees, and obstacles in the field in the form of mass mobilization by the Respondent for execution. If the execution of the decision is immediately delayed (uitvoerbaar bij voorraad), the District Court of Kabanjahe takes measures to overcome the delay in execution. In the event that the execution of the decision is immediately hampered because the chairman of the Medan High Court has not issued an execution permit immediately, then the only way to implement the contents of the decision is to wait until the decision has permanent legal force. If the execution delay is due to the inability of the execution applicant to provide guarantees, then the Chief of the Kabanjahe District Court will advise the execution applicant to borrow money from family or relatives, friends, or the bank. In the event that the execution is delayed due to obstacles in the field, the Court bailiff and the police will take persuasive efforts. the Head of the Kabanjahe District Court will advise the execution applicant to borrow money from family or relatives, friends, or the bank. In the event that the execution is delayed due to obstacles in the field, the Court bailiff and the police will take persuasive efforts. the Head of the Kabanjahe District Court will advise the execution applicant to borrow money from family or relatives, friends, or the bank. In the event that the execution is delayed due to obstacles in the field, the Court bailiff and the police will take persuasive efforts.
\end{abstract}

This is an open access article under the CC BY-NC license. 


\section{Introduction}

Considering the potential for conflict to arise in human relations, legal norms are established with the aim of maintaining peace, justice and protection of rights in a society. According to Satjipto Rahardjo, the presence of law in society, among others, is to integrate and coordinate interests that can conflict with each other, by law being integrated in such a way that these collisions can be minimized.

Disturbances of interests or conflicts must be prevented and not allowed to continue because they will disrupt the balance of the social order.

Conflicts that are not resolved or allowed to continue will escalate into disputes. Civil disputes can be resolved through litigation or non-litigation. Settlement of civil disputes through litigation is carried out by submitting disputes to the Court, while dispute resolution through non-litigation channels is carried out outside the Court by means of consultation. ${ }^{9}$, negotiation $^{10}$, mediation ${ }^{11}$, conciliation ${ }^{12}$, or expert judgment.

In the life of a modern state, formal courts are present together with the development of modern legal society. The formal courts hold judicial powers according to the country's constitution, to be the enforcers of law and justice. ${ }^{14}$ The judiciary plays an important role, because it is the only formal institution that is mandated to manage all legal issues of every citizen who has difficulty in seeking justice.

Any person who feels aggrieved or feels that his interests are disturbed can file a lawsuit against the party deemed to have harmed him through the Court. The lawsuit must be formally addressed and addressed to the District Court according to relative competence.

Relative competence is the authority of a judicial body to examine, hear, and decide a case based on its jurisdiction. If the lawsuit is addressed to a Court that is not in accordance with its relative competence, then the lawsuit contains a formal defect because the lawsuit is submitted and addressed to a District Court which is outside the territory of the District Court which is authorized to examine and hear the case. Thus, the lawsuit will be declared unacceptable (niet onvankelijke verklaard) on the grounds that the judge is not authorized to try.

Identity in the lawsuit is a formal requirement for the validity of the lawsuit. If the claim letter does not mention the identity of the parties, it will cause the lawsuit to be invalid and considered non-existent. The identity that must be mentioned is the full name and address or place of residence. Other identities such as age, occupation, religion, gender, and ethnicity are not prohibited from mentioning. The more complete, of course, the better and more certain.

Fundamentum patenti which is also known as a positum (the plural is called posita) a lawsuit, or in Indonesian it is called the argument of a lawsuit, is the basis of a lawsuit or the basis of a claim. The patented fundamentum contains two elements, namely: 19

a. The legal basis (rechtelijke grond) contains an affirmation or explanation regarding the legal relationship between the Plaintiff and the disputed material and/or object, and between the Plaintiff and the Defendant relating to the disputed material or object.

b. Basis of Facts (Feitelijke grond) contains an explanation of statements regarding facts or events that are directly related to or around the legal relationship that occurs between the Plaintiff and the material or object of the case or the Defendant, or an explanation of facts that are directly related to the legal basis or legal relationship that argued by the Plaintiff.

Petitum or claim is what the Plaintiff is asking or hoping to decide by the Judge. So, the demands will be answered in the order or dictum of the decision. There are several terms that have the same meaning as petitum, such as petita or petitory or conclusum. However, the 
standard and most frequently used term in judicial practice is petitum or principal claim. ${ }^{21} \mathrm{~A}$ claim can be divided into 3 (three), namely:22

a. The primary claim or the main claim that is directly related to the subject matter;

b. additional demands, not the main demands but still have something to do with the main case;

c. subsidiary claims or substitute claims.

Another factor that became the reason for the Plaintiff to include the claim uitvoerbaar bij voorraad in the petitum of his lawsuit is to protect the interests of the creditor as the Plaintiff from the attitude of the debtor (Defendant) who has bad intentions. The judicial process that takes a long time will make the debtor (Defendant) feel protected. The losing debtor (Defendant) may file various legal remedies with the intention of delaying the fulfillment of its obligations for a long period of time. For this reason, the Plaintiff in his petition often asks that the decision be implemented immediately.

The request for the decision to be carried out immediately in the petitum of the lawsuit as is often encountered in practice is in line with the wishes of the community and justice seekers who demand that the settlement of cases through the Court be carried out in accordance with the principles of a simple, fast and low cost trial.

A simple judicial process means an uncomplicated legal process. Simplicity of proceedings means the simplicity of the judicial process that does not use complicated or long-winded procedures and uses too many formalities. Sudikno Mertoksumo said that the fewer and simpler the formalities required or required in proceedings before the Court, the better the proceedings.

Fast trial means a trial that does not take long so that the winning party can immediately enjoy his victory. Too much formality is an obstacle to the judiciary. The speed of the judicial process will increase public confidence in the Court. 25

A low-cost trial means a court that does not cost a lot of money so that it can be reached by the community. The high cost of the case causes interested parties to be reluctant to file a claim to the Court.

If the demand for uitvoerbaar bji voorraad is granted, the judge will issue a decision that can be executed even though the decision has not yet become legally binding. As is known, the ultimate goal of the case examination process in the District Court is to make a decision by the judge containing the settlement of the disputed case. In the decision, the rights and legal relationship of the parties to the object in dispute are determined with certainty.

The decision taken by the judge has not completed the case completely if the decision is not implemented or executed. The winning party certainly does not want his victory to be only on paper, but there must be implementation of the decision. For the winning party, the final goal to be achieved has not been carried out if the implementation of the decision has not been carried out.

In principle, only decisions that have obtained permanent legal force can be executed. A decision has permanent legal force when there are no more ordinary legal remedies available, such as resistance (verzet), appeal, and cassation. Decisions that have permanent legal force cannot be changed anymore, where the legal relationship between the litigants is fixed and certain. 


\section{Method}

The research that will be carried out by the author in the context of preparing this thesis is normative research and sociological research. Normative research is conducted by examining laws and regulations, legal materials, and other materials related to the writing of this thesis. The author's sociological research was conducted by conducting research at the Kabanjahe District Court as one of the implementers of judicial power in Indonesia.

Primary legal materials, namely legal rules contained in various legal instruments or statutory regulations, including: Herziene Indonesische Reglement (HIR), Rechtsreglement voor de Buitengewesten (Rbg), Circular Letter of the Supreme Court of the Republic of Indonesia (hereinafter referred to as SEMA RI), and etc.

Secondary legal materials, namely legal materials obtained from textbooks, scholar opinions, internet media, and others. Tertiary legal materials, namely legal materials that provide meaningful instructions or explanations for primary legal materials and secondary legal materials such as Indonesian language dictionaries and legal dictionaries.

3. Analysis and Results.

\subsection{Immediate Execution Of Decisions (Uitvoeerbaar Bij Vooraad) In Civil Cases in Kabanjahe State Court}

\section{a. Overview Of Kabanjahe District Court}

According to Article 4 paragraph (1) of Law No. 8 of 2004 concerning Amendments to Law No. 2 of 1986 concerning General Courts, the District Court is domiciled in the capital city of the district/city and its jurisdiction covers the territory of the district/city.

The Kabanjahe District Court is located in the capital city of Karo Regency, precisely at Jalan Jamin Ginting Number. 9 Kabanjahe. The jurisdiction of the Kabanjahe District Court covers the area of Karo Regency, which is divided into several sub-districts, namely Barusjahe District, Juhar District, Kabanjahe District, Kutabuluh District, Lau Baleng District, Marwall District, Brand District, Munte District, Payung District, Simpang Empat District, and Tigabinanga District.

\subsection{Immediate Execution Procedures at The Kabanjahe District Court}

Decisions are immediately useful in fast, cheap and simple law enforcement. The verdict was immediately a breakthrough against the slow judicial process. Through this institution, the Court's decision can be executed even though the decision has not yet obtained permanent legal force.

Judgment will be meaningless without execution. The execution of the decision immediately has a different procedure from the usual execution. This sub-chapter will explain the procedure for the immediate execution of decisions at the Kabanjehe District Court.

The execution of the decision is immediately distinguished between the real execution and the execution of the payment of a sum of money. As explained in the previous chapter, the real execution is easier and simpler, while the execution of the payment of a sum of money is more complicated because it requires execution confiscation and execution sales (execution auction) stages.

The following is the actual execution procedure for the decision immediately at the Kabanjahe District Court : 
a. The applicant for execution submits an application for execution to the Head of the Kabanjahe District Court so that the Kabanjahe District Court implements the decision immediately handed down by the Judge. The application is submitted to the Head of the Kabanjahe District Court through the General Section of the Kabanjahe District Court to be further forwarded to the Registrar.

b. After reading the request for execution and the decision to be executed, the Head of the Kabanjahe District Court wrote to the Chairman of the Medan High Court to request that the execution be carried out immediately.

The files sent by the Head of the Kabanjahe District Court to the Chairman of the Medan High Court are:

1) the petition for execution submitted by the Petitioner for execution to the Head of the Kabanjahe District Court;

2) complete case file;

3) opinion of the Chairman of the Kabanjahe District Court.

c. The Chairman of the Medan High Court immediately studied the decision that was requested for execution, and gave permission to execute it immediately if the Chairman of the Medan High Court was of the opinion that the conditions stated in Article 191 paragraph (1) Rbg and SEMA RI No. 3 of 2000 Jo. SEMA RI No. 4 of 2001 has been fulfilled.

d. The Head of the Kabanjahe District Court ordered the Kabanjahe District Court bailiff to summon the Respondent for execution to be given a warning (aanmaning). The command is issued in an assignment. In this determination, the Head of the Kabanjahe District Court determines the day, date, time, and place where the Respondent for execution must appear before the Chairman of the Kabanjahe District Court.

e. The bailiff of the Kabanjahe District Court summoned the Respondent for execution and submitted a copy of the minutes of summons. Calls are made directly to the Respondent for execution. If the Respondent for execution is not present, the summons will be made through the Village Head or Lurah.

f. If the Respondent for execution complies with the summons from the Head of the Kabanjahe District Court, the decision will be read to him and a warning or reprimand for the Respondent for executing the decision voluntarily within 8 (eight) days. If the Respondent for execution does not fulfill the summons, even though the summons was delivered directly to him, then the right of the Respondent for execution to be reprimanded/commemorated becomes null and there is no need for another summons to be made. However, if the call is made through the Village Head or Lurah, then the summons must be carried out one more time.

g. The head of the Kabanjahe District Court also summoned the applicant for execution to submit a guarantee whose value is equal to or greater than the object to be executed.

h. If within a period of 8 (eight) days after the execution of the Respondent, the Respondent does not carry out the decision, the Head of the Kabanjahe District Court shall make a decision granting the request for execution by issuing an execution order. The execution order contains an order to the Registrar or Bailiff appointed to carry out the execution in accordance with the decision ordered. The head of the Kabanjahe District Court also made a decision that contained a guarantee of immediate execution. Without the provision of guarantees, execution cannot be carried out immediately.

Meanwhile, the procedure for the execution of the payment of a sum of money against the decision must immediately go through the stage of confiscation of execution and sale of the auction. The following will explain the procedure for the execution of the payment of a sum of money against an immediate decision:

a. The applicant for execution submits an application for execution immediately to the Head of the Kabanjahe District Court.

b. The head of the Kabanjahe District Court submitted a request for execution immediately to the Chairman of the Medan High Court. 
c. The head of the Medan High Court issued an execution permit immediately.

d. The Head of the Kabanjahe District Court ordered the Kabanjahe District Court bailiff to summon the Respondent for execution to be given a warning (aanmaning).

e. The bailiff of the Kabanjahe District Court summoned the Respondent for execution and submitted a copy of the minutes of summons.

f. The Head of the Kabanjahe District Court ordered the execution of the Respondent.

g. The head of the Kabanjahe District Court also summoned the Executioner to submit bail.

h. If within a period of 8 (eight) days after the execution of the Respondent does not carry out the decision, the Head of the Kabanjahe District Court will ex officio issue a letter of determination containing an order to the Registrar or Bailiff to carry out an execution confiscation (executoriaal beslag). The head of the Kabanjahe District Court also issued an immediate guarantee of execution.

i. Based on the order to confiscate the execution, the Registrar or bailiff will carry out the execution confiscation of the goods listed in the decision to be executed. Then, the Registrar or bailiff makes a report on the confiscation of execution.

\subsection{The Relationship between Guarantees and Immediate Execution of Decisions}

Decisions that contain an immediate order (uitvoerbaar bij voorraad) carry the risk that the decision may be overturned by the High Court or the Supreme Court. The possibility of annulling the decision by the High Court or the Supreme Court raises a new problem, namely the difficulty of restoring execution to its original state. For example, the Judge handed down a decision containing a directive in which the decision sentenced the Defendant to hand over the land in question to the Plaintiff accompanied by an order to demolish the existing building on the land. If the decision is later overturned by the High Court or Supreme Court,

To prevent difficulties that may arise from the sudden cancellation of the decision by the High Court or the Supreme Court, the Plaintiff (the applicant for execution) is obliged to submit an execution guarantee to the District Court before the execution is carried out. The purpose of the guarantee is to facilitate recovery or rehabilitation if the decision that was implemented earlier is canceled at the level of appeal or cassation. In the example above, if the building on the land of the case has been demolished, then the building can be rebuilt using the collateral that has been submitted by the Executioner.

\subsection{Barriers to Immediate Execution of Decisions at the Kabanjahe District Court}

Execution of decisions immediately (uitvoerbaar bij voorraad) in practice often encounters various obstacles. The District Court as the spearhead of implementing the immediate decision execution (uitvoerbaar bij voorraad) often encounters these obstacles. The Kabanjahe District Court has also experienced problems which resulted in the immediate delay in the execution of the decision.

The following are obstacles in the immediate execution of decisions (uitvoerbaar bij voorraad) at the Kabanjahe District Court:

a. The chairman of the Medan High Court did not immediately issue an execution permit;

b. The applicant for execution is unable to submit a guarantee;

c. Obstacles in the field.

The execution permit may be refused by the Chairperson of the Medan High Court. In other cases, the Chief Justice of the Medan High Court may not respond to the permit application. The chairman of the Medan High Court does not issue an execution permit immediately if the 
conditions for imposing a decision immediately as regulated in Article 191 paragraph (1) Rbg and SEMA RI are not met.

In the event that the Chairperson of the Medan High Court does not issue an execution permit, then the execution cannot immediately be carried out. Cases like this have occurred in the Kabanjahe District Court Decision dated June 1, 2009 No. 55/Pdt.G/2008/PN.Kbj. The decision is passed on the condition that it can be executed first. However, the Chairman of the Medan High Court did not issue an execution permit for the decision because it was deemed not to meet the requirements of the decision as regulated in Article 191 paragraph (1) Rbg, SEMA RI No. 3 of 2000 Jo. SEMA RI No. 4 of 2001. As a result, the decision cannot be executed immediately.

\subsection{Response to the Decision of the Kabanjahe District Court No.65/Pdt.G/2007/PN.Kbj}

a. Position Case

The Kabanjahe District Court has several times handed down decisions with conditions that they can be executed first (uitvoerbaar bij voorraad). The following table will present a data table of decisions immediately handed down by the Kabanjahe District Court in the last 5 (five) years:

\begin{tabular}{lcccc} 
Table 1. Data on Civil Cases for the Period 2006-2010 Kabajahe District Court \\
\hline Year & $\begin{array}{c}\text { lawsuit } \\
\text { Enter }\end{array}$ & $\begin{array}{l}\text { Decision Join } \\
\text { Separate } \\
\text { d }\end{array}$ & $\begin{array}{l}\text { Remaining } \\
\text { Lawsuit }\end{array}$ \\
\hline 2005 & 52 & 59 & - & 26 \\
2006 & 66 & 54 & - & 19 \\
2007 & 58 & 72 & 1 & 31 \\
2008 & 53 & 47 & 1 & 17 \\
2009 & 45 & 37 & - & 23 \\
2010 & 274 & 269 & 2 & 31 \\
Amount & & &
\end{tabular}

From the data table above, it is known that the Kabanjahe District Court rarely makes decisions immediately. In the period 2006 to 2010, the Kabanjahe District Court decided 269 civil cases. Of the 269 cases, only two cases were decided by amar uitvoerbaar bij voorraad, namely the decision of the Kabanjahe District Court No.65/Pdt.G/2007/PN.Kbj dated July 10, 2008 and the decision of the District Court of Kabanjahe No. 55/Pdt.G/2008/PN.Kbj dated June 1, 2009. Both decisions were immediately rendered with the consideration that the lawsuit is supported by authentic documents of evidence in the form of decisions that have permanent legal force.

Both decisions have been executed by the Kabanjahe District Court although they were delayed. Kabanjahe District Court Decision No. 65/Pdt.G/2007/PN.Kbj dated July 10, 2008 was hampered due to obstacles in the field in the form of mass mobilization by the Respondent for execution who did not accept the execution. While the decision of the Kabanjahe District Court No. 55/Pdt.G/2008/PN.Kbj dated June 1, 2009 was delayed because the Chairman of the Medan High Court did not issue an execution permit immediately because according to him, the conditions for the imposition of a verdict had not yet been fulfilled. Therefore, this decision cannot be executed immediately. The execution of this decision is carried out through the usual execution procedure after the decision is final and binding.

In this sub-chapter one of the two decisions immediately handed down by the Kabanjahe District Court as mentioned above will be discussed. One of the decisions that were immediately handed down and executed by the Kabanjahe District Court was the Kabanjahe 
District Court's decision no. 65/Pdt.G/2007/PN.Kbj, between the heirs of the late. Milang Purba and the late. Well Br Milala represented by his children:

1) Yuslinda Harum Br Purba, 44 years old, work as a housewife;

2) Enita Clara Br Purba, 39 years old, work as a housewife;

3) Epi Pana Br Purba, 39 years old, working as a housewife;

4) Viator Bastanta Purba, 38 years old, self-employed, in this case acting for himself or representing the legal interests of Egia Ananda Tarigan who is still a minor, as heir of the late. Takasima Br Purba ;

5) Pius Pana Purba, 37 years old, self-employed;

6) Milana Br Purba, 34 years old, work as a housewife;

Hereinafter referred to as the Plaintiffs, against the heirs of the late. Ask for Purba and the late. Tama Sembiring, namely:

1) Andreas Purba, BEC;

2) Johanna Br Purba ;

3) Rosdeliana Br Purba ;

4) Josephina Br Purba ;

5) Ancient France;

6) Sabrina Ita Br Purba ;

7) Ancient Augustine ;

Approximately $58.5 \mathrm{~m} 2$ along with the house building on it which is located at Jalan Captain Bangsi Sembiring No. 53, where the Plaintiffs in the civil decision No.03/Pdt.Plw/2001/PN.Kbj Jo. No. 357/Pdt/2003/PT. Mdn Jo. 2461K/Pdt/2005 which has permanent legal force is declared as the winning party and has the right to the object based on the inheritance from the late. Ancient Milan.

Whereas previously the Defendants had filed a lawsuit in a civil case No.40/Pdt.G/1995/PN.Kbj Jo. No.70/Pdt/1996/PT.Mdn Jo. No.1925K/Pdt/1997 with the object of the case mentioned above, and has been executed, and the land is under the control of the Defendants. In this case, the aquo Plaintiffs did not participate as parties.

That on the plan to execute the decision in case No.40/Pdt.G/1995/PN.Kbj Jo. No.70/Pdt/1996/PT.Mdn Jo. No.1925K/Pdt/1997, the Defendants have filed a lawsuit registered in the civil case No. 03/Pdt.Plw/2001/PN.Kbj Jo. No. 357/Pdt/2003/PT. Mdn Jo. $2461 \mathrm{~K} / \mathrm{Pdt} / 2005$ which has permanent legal force, which essentially states that the object of the case belongs to the aquo Plaintiffs.

In the decision of the case No.03/Pdt.Plw/2001/PN.Kbj Jo. No. 357/Pdt/2003/PT. Mdn Jo. $2461 \mathrm{~K} / \mathrm{Pdt} / 2005$, the Plaintiffs aquo are declared the owners of the object of the case. However, in the decision, there is no dictum for submitting the object of the case to the aquo Plaintiffs.

Based on the reasons mentioned above, the Plaintiffs filed an aquo lawsuit regarding the submission of the object of the case to implement the case decision No.03/Pdt.Plw/2001/PN.Kbj Jo. No. 357/Pdt/2003/PT. Mdn Jo. 2461K/Pdt/2005. One of the petitums in the Plaintiffs' lawsuit is to request that the decision handed down by the Panel of Judges be implemented immediately.

The Defendants denied the arguments of the lawsuit and requested that the Plaintiffs' claim be declared rejected or at least unacceptable.

To prove the arguments of their lawsuit, the Plaintiffs submitted seven documentary evidences, three of which are court decisions, namely:

1) Kabanjahe District Court Decision No. 03/Pdt.plw/2001/PN.Kbj dated June 24, 2002;

2) Medan High Court Decision No. 357/Pdt/2003/PT.Mdn dated April 26, 2004; and

3) Supreme Court Decision No. 2461K/Pdt/ 2005 dated June 5, 2006. 
The evidence mentioned above has permanent legal force, where in the decision the Plaintiffs are declared to be the heirs of the late. Milang Purba and has the right to the object of the case.

Meanwhile, the Defendants submitted nine documentary evidences and presented two witnesses to prove their rebuttal argument. However, the Panel of Judges considered that none of the evidence from the letters and witness statements presented by the Defendants could invalidate the legal considerations of the Supreme Court's decision No.2461K/Pdt/2005 Jo. Medan High Court Decision No. 357/Pdt/2003/PT. Mdn Jo. the decision of the Kabanjahe District Court No.03/Pdt.Plw/2001/PN.Kbj which has permanent legal force.

To prove the arguments of their lawsuit, the Plaintiffs submitted seven documentary evidences, three of which are court decisions, namely:

1) Kabanjahe District Court Decision No. 03/Pdt.plw/2001/PN.Kbj dated June 24, 2002;

2) Medan High Court Decision No. 357/Pdt/2003/PT.Mdn dated April 26, 2004; and

3) Supreme Court Decision No. 2461K/Pdt/2005 dated June 5, 2006.

The evidence mentioned above has permanent legal force, where in the decision the Plaintiffs are declared to be the heirs of the late. Milang Purba and has the right to the object of the case.

Meanwhile, the Defendants submitted nine documentary evidences and presented two witnesses to prove their rebuttal argument. However, the Panel of Judges considered that none of the evidence from the letters and witness statements presented by the Defendants could invalidate the legal considerations of the Supreme Court's decision No.2461K/Pdt/2005 Jo. Medan High Court Decision No. 357/Pdt/2003/PT. Mdn Jo. the decision of the Kabanjahe District Court No.03/Pdt.Plw/2001/PN.Kbj which has permanent legal force.

Based on the above considerations, the Panel of Judges concluded that the Plaintiffs had been able to prove the arguments for their lawsuit and therefore had the right to the object of the case.

Because the object of the case has been proven to belong to the Plaintiffs, the Panel of Judges grants the petition of the Plaintiffs which contains an application to punish the Defendants or other people who have obtained rights from them to hand over the litigated land covering an area of $58.5 \mathrm{~m} 2$ along with the building on it to the Plaintiffs. The plaintiff is empty and good without any hindrance.

The Panel of Judges also granted the petition of the Plaintiffs which contained a request that the decision could be implemented immediately even though there was a verzet, appeal, or cassation, with the consideration that the Plaintiffs' claims were supported by authentic documents, namely decisions that had permanent legal force in accordance with with the provisions of Article 191 paragraph (1) Rbg and SEMA RI Number 3 of 2000.

Kabanjahe District Court Decision No. 65/Pdt.G/2007/PN.Kbj was executed immediately on August 6, 2009 based on the stipulation chairman Court Country Kabanjahe No. 02/Pen. Eksekusi/2009/PN. Kbj.

The execution of this decision had encountered obstacles in the field, namely because of the mass mobilization by the Execution Respondent who did not accept the execution process. However, the execution could still be carried out with the help of security forces from the Tanah Karo Police who stated their readiness and ability to deal with the crowd.

b. Response 
The immediate decision (uitvoerbaar bij voorraad) in case No. 65/Pdt.G/2007/PN.Kbj is correct because it meets the requirements for the immediate imposition of a decision as stipulated in Article 180 paragraph (1) HIR or Article 191 paragraph (1) Rbg, as well as SEMA RI No. 3 of 2000 Jo. SEMA RI No. 4 of 2001. The Panel of Judges in their deliberations was of the opinion that the decision was immediately appropriate to be handed down in the aquo case because the Plaintiff's claim was supported by authentic documents of evidence, namely decisions that had permanent legal force. The decisions in question are:

1) Kabanjahe District Court Decision No. 03/Pdt.plw/2001/PN.Kbj dated June 24, 2002;

2) Medan High Court Decision No. 357/Pdt/2003/PT.Mdn dated April 26, 2004; and

3) Supreme Court Decision No. 2461K/Pdt/2005 dated June 5, 2006.

The immediate execution procedure for this decision has also been complied with properly. The execution of this decision immediately begins with a request for execution by Br. Aldian Pinem who acted as attorney for Yuslinda Harum Br Purba et al (applicant for execution).

Based on the request for execution, the Head of the Kabanjahe District Court requested the execution of the Medan High Court immediately, through a letter dated 18 September 2008 No.W2.U7.1602/HT.04.10/IX/2008. After studying the decision of the Kabanjahe District Court dated July 31, 2008 No. 65/Pdt.G/2007/PN.Kbj, Chairman of the Medan High Court issued a letter dated March 10, 2009 No. W2.U/1086/HT.E/III/2009 which in essence gave an immediate execution permit for the case because it was deemed to have met the conditions for an immediate decision.

After the Chairman of the Medan High Court gave permission to carry out the execution immediately, the Chairman of the Kabanjahe District Court issued an aanmaning decree which contained:

1) Receive an execution request from the Petitioner;

2) Ordered the brother of Perdamenta Purba, the bailiff of the Kabanjahe District Court, to summon the Respondent for execution;

3) Requesting the assistance of the Chairman of the Medan District Court to order one of the bailiffs or his successor bailiff to summon the execution defendants to appear before the head of the Kabanjahe District Court on Wednesday, April 15 2009, at 10.00 WIB, at the Kabanjahe District Court Building.

Because the Respondents for execution were outside the jurisdiction of the Kabanjahe District Court, the summons for the Respondent for execution was carried out by Belinun Sembiring, Substitute Bailiff at the Medan District, Commercial, Human Rights and PHI Courts. Belium Sembiring made summons to the Respondents ek FRRR'Ty.

\section{Conclusion}

The existence of a guarantee by the applicant for execution is one of the conditions for the immediate execution of the decision. Without this guarantee, the execution of the decision cannot be carried out immediately. The purpose of the guarantee is to facilitate recovery or rehabilitation if the decision that was implemented earlier is canceled at the level of appeal or cassation.

The obstacles in the immediate execution of decisions (uitvoerbaar bij voorraad) at the Kabanjahe District Court are as follows: The chairman of the Medan High Court did not immediately issue an execution permit, The applicant for execution is unable to submit a guarantee, Obstacles in the field, namely the presence of mass mobilization by the Respondent for execution, The efforts taken by the Kabanjahe District Court in overcoming the delay in the execution of the decision are immediately as follows: In the event that the execution of the decision is immediately hampered because the Head of the High Court has not issued an 
execution permit immediately Medan, then the execution of the decision cannot be carried out. The only way to implement the contents of the decision is to wait until the decision has permanent legal force. If the decision has permanent legal force, execution can be carried out by following the usual procedures, In the event that the execution of the decision is immediately hampered because the execution applicant is unable to submit a guarantee, the Head of the Kabanjahe District Court will advise the execution applicant to first borrow money from family or relatives, friends, or the bank. However, if the suggestion does not work, then the only way for the decision to be implemented is for the petitioner for execution to wait until the decision has permanent legal force. In the event that the execution of the decision is immediately hampered due to obstacles in the field in the form of mass mobilization by the Respondent, the Court bailiff and the police in charge of securing the execution will take persuasive efforts. If the persuasion efforts are not successful, the bailiff will inquire about the readiness and ability of the security forces.

\section{References}

Dja'is, Mochammad. 2004. Basic Thoughts on Execution Law. Faculty of Law, Diponegoro University: Semarang.

Hermansyah. 2009. Diktat of Civil Procedure Law Lectures. Faculty of Law, University of North Sumatra: Medan.

Please, M. Yahya. 2006. Scope of Execution Issues in the Civil Sector. Sinar Graphic: Jakarta.

2005. Civil Procedure Law. Sinar Graphic: Jakarta. Kansil, CST 1992. Introduction to Law. Library Center: Jakarta.

Mertokusumo, Sudikno. 2002. Indonesian Civil Procedure Code. Liberty: Yogyakarta.

1999. Knowing the Law (An Introduction). Liberty: Yogyakarta.

Mulyadi, Lilik. 1999. Civil Procedure Law according to the Theory and Practice of the Indonesian Judiciary. Bridge: Jakarta.

1997. Provisionil Claims in Civil Procedure Law in Judicial Practice. Bridge: Jakarta.

Muttaqien, Dadan. 2006. Basic Civil Procedure Law. Insania Cita Press: Yogyakarta.

Nasir, M. 2003. Civil Procedure Law. Bridge: Jakarta.

Print, Darwan. 1996. Strategies for Developing and Handling Civil Lawsuits. Image of Aditya Bakti: Bandung.

Rahardjo, Satjipto. 2006. Legal Studies. Image of Aditya Bakti: Bandung. Rasaid, M. Nur. 1999. Civil Procedure Law. Sinar Graphic: Jakarta.

lucky. 2004. Alternative Dispute Resolution. Pustaka Bangsa Press: Medan. Saifullah, 2007. Reflections on Sociology of Law. Refika Aditama: Bandung.

Saleh, K. Wantjik. 1981. Civil Procedure Code Rbg / HIR. Ghalia Indonesia: Jakarta.

Sayuthi, Wildan. 2004. Seizures and Executions: Court Justice Practices.

Simorangkir JCT \& Rudy T. Erwin. 2009. Legal Dictionary. Sinar Graphic: Jakarta.

Soeparmono, R. 2005. Civil Procedure Law and Jurisprudence. Mandar Maju: Bandung.

Soeroso, R. 2009. Practice of Civil Procedure Law: Procedures and Court Process. Sinar Graphic: Jakarta. 
Subekti, R. \& Tjitrosoedibio. 2008. Legal Dictionary. Pradnya Paramita: Jakarta. Subekti, R. 2008. Law of Evidence. Pradnya Paramita: Jakarta.

.1997. Civil Procedure Law, Bina Cipta: Bandung. Sudarsono, 2007. Legal Dictionary (New Edition). Asdi Mahasatya: Jakarta.

Sutantio, Retnowulan. 1997. Civil Procedure Law in Theory and Practice.

Mandar Maju: Bandung.

Syahrani, Riduan. 2004. Book of Basic Materials for Civil Procedure Law. Image of Aditya Bakti: Bandung .1988. Civil Procedure Law in General Courts.

Kartini Library: Jakarta.

Law No. 3 of 2009 concerning the Second Amendment to Law no. 14 of 1985 concerning the Supreme Court

Law Number 49 of 2009 concerning the Second Amendment to Law Number 2 of 1986 concerning General Courts

Law No. 11 of 2008 concerning Information and Electronic Transactions.

Law No. 5 of 2004 concerning Amendments to Law Number 14 of 1985 concerning the Supreme Court.

Law No. 8 of 2004 concerning Amendments to Law Number 2 of 1986 concerning General Courts.

Law Number 2 of 1986 concerning General Courts. Law Number 14 of 1985 concerning the Supreme Court. Republic of Indonesia Supreme Court Circular No. 4 of 2001.

Republic of Indonesia Supreme Court Circular No. 3 of 2000 dated July 21, 2000.

Republic of Indonesia Supreme Court Circular No. 3 of 1978 dated April 1, 1978.

Circular Letter of the Supreme Court of the Republic of Indonesia No. 6 of 1975 dated December 1, 1975.

Republic of Indonesia Supreme Court Circular No. 3 of 1971 dated May 17, 1971.

Republic of Indonesia Supreme Court Circular No. 5 of 1969 dated June 2, 1969.

Republic of Indonesia Supreme Court Circular No. 13 of 1964 dated July 10, 1964.

RI Supreme Court. 2004. Guidelines for the Implementation of Duties and Administration of Courts Book II (5th printing). Jakarta: The Supreme Court of the Republic of Indonesia.

RI Supreme Court. 2003. Anthology of Civil Procedure Law. Jakarta: The Supreme Court of the Republic of Indonesia.

Research and Development Center for Education and Training of the Supreme Court - RI. 1997. Decisions That Can Be Implemented In Advance. Jakarta: The Judicial Technical Development Project for the Supreme Court - RI. 